\title{
Method for Assessing Effectiveness of Company Digital Transformation: Integrated approach
}

\author{
Alexander KUNTSMAN and Igor Anatolevich ARENKOV \\ Saint Petersburg State University, Moscow, Russia
}

Correspondence should be addressed to: Alexander Kuntsman; kuntsman@gmail.com

Received date: 12 February 2019; Accepted date: 23 April 2019; Published date: 24 June 2019

Academic Editor: Liudmila Oveshnikova

Copyright (C) 2019. Alexander KUNTSMAN and Igor Anatolevich ARENKOV. Distributed under Creative Commons CC-BY 4.0

\begin{abstract}
The paper is devoted to the problems of assessing the effectiveness of digital business transformation. The author reviews the existing approaches to assessment, identifies the most representative methods and develops an integrated approach to evaluating the effectiveness of company digital transformation. This approach involves the use of a number of traditional qualitative and quantitative methods: balanced scorecard, the total cost of ownership, investment analysis methods, etc. Practical aspects of the developed approach application are illustrated on the example of the Russian printing company.
\end{abstract}

Keywords: digital economy, efficiency of digital transformation, qualitative approach, quantitative approach.

\section{Introduction}

The increasing role of information and knowledge in business, the need to reduce production costs and the rapid development of digital information technologies have created a new type of economy - the digital economy (Andriole, 2017).

The fundamental changes in the sphere of company management, which take place under the influence of the digital economy, have been in the focus of theoretical and practical research for many years. These

Cite this Article as: Alexander KUNTSMAN and Igor Anatolevich ARENKOV (2019)," Method for Assessing Effectiveness of Company Digital Transformation: Integrated approach", IBIMA Business Review, Vol. 2019 (2019), Article ID 334457, DOI: 10.5171/2019.334457 
changes have led to the emergence of a new economic paradigm in recent decades (Early, 2014). Scholars have explored many aspects of business digital transformation. However, the analysis of literature sources showed that currently there is no method of assessing the effectiveness of digital transformation, which, on the one hand, would be scientifically sound, and on the other hand would be applicable in the practical conditions of developing countries. Existing and applied practice methods of performance evaluation either do not take into account all aspects of the company's activities, or are resourceintensive and expensive. The use of these methods is impossible without the involvement of consulting firms.

The analysis of publications on the problem of assessing the effectiveness of digital transformation, as well as the practical experience of the author of this work show that in Russia and other developing countries, many top managers do not fully realize the importance of assessing the effectiveness of digitalization, but there is a clear trend of strengthening this understanding. Consequently, in the next few years, the problem of filling existing gaps in evaluation methodologies will become even more significant.

The above facts show the relevance of practical research aimed at improving the methodology for analyzing the effectiveness of investments in digital transformation projects of companies operating in the specific conditions of developing countries.

Analysis of existing approaches to assessing the economic efficiency of company digital transformation

Currently, there are quite a number of methods for evaluating the effectiveness of projects in the field of digital transformation (Westerman, Bonnet, 2015). Table 1 presents a comparative analysis of the advantages and disadvantages of the most popular techniques.

Table 1: Comparative analysis of some groups of techniques used to assess the effectiveness of digital transformation

\begin{tabular}{|c|c|c|c|}
\hline № & $\begin{array}{l}\text { Groups of techniques, } \\
\text { techniques }\end{array}$ & Pros & Cons \\
\hline I & $\begin{array}{l}\text { Based on cost accounting or } \\
\text { minimization (TCO, etc.) }\end{array}$ & $\begin{array}{l}\text { Full accounting of all costs } \\
\text { types and their ratio to cost } \\
\text { sources }\end{array}$ & $\begin{array}{l}\text { They do not provide an } \\
\text { opportunity to fully } \\
\text { assess the benefits and } \\
\text { advantages of integrating } \\
\text { digital technologies into } \\
\text { business. }\end{array}$ \\
\hline II & $\begin{array}{l}\text { Investment analysis } \\
\text { techniques }\end{array}$ & $\begin{array}{l}\text { Detailed and most reliable } \\
\text { construction of the cash } \\
\text { flow scheme, which } \\
\text { characterizes the project } \\
\text { profitability. }\end{array}$ & $\begin{array}{l}\text { There is no } \\
\text { consideration of the } \\
\text { peculiarities of digital } \\
\text { technologies, and there } \\
\text { is no possibility to } \\
\text { estimate the costs and } \\
\text { benefits of the project. }\end{array}$ \\
\hline \multirow[t]{3}{*}{ III } & Integral techniques & & \\
\hline & $\begin{array}{l}\text { 3.1. "Balanced" (example: } \\
\text { balanced scorecard) }\end{array}$ & $\begin{array}{l}\text { Assessment of all } \\
\text { company's activities, taking } \\
\text { into account past and } \\
\text { future trends. }\end{array}$ & $\begin{array}{l}\text { Complex and resource- } \\
\text { intensive in the process } \\
\text { of application and } \\
\text { construction. }\end{array}$ \\
\hline & $\begin{array}{l}\text { 3.2. «Risky» (example: real } \\
\text { options valuation, ROV) }\end{array}$ & $\begin{array}{l}\text { The most accurate and } \\
\text { complete assessment of all } \\
\text { risks and company }\end{array}$ & $\begin{array}{l}\text { Complex implementation } \\
\text { and the need for a } \\
\text { cumbersome statistical }\end{array}$ \\
\hline
\end{tabular}




\begin{tabular}{|l|l|l|l|}
\hline & & $\begin{array}{l}\text { preparedness to work } \\
\text { under uncertainty. }\end{array}$ & $\begin{array}{l}\text { and mathematical } \\
\text { apparatus. }\end{array}$ \\
\hline IV & $\begin{array}{l}\text { Original methods of } \\
\text { consulting companies (TVO, } \\
\text { etc.)) }\end{array}$ & $\begin{array}{l}\text { Detailed assessment of all } \\
\text { areas of firm's activities } \\
\text { that are subject to } \\
\text { significant impact of digital } \\
\text { technologies. }\end{array}$ & Closed techniques \\
\hline V & Other techniques & $\begin{array}{l}\text { Rapid assessment (often } \\
\text { simplified) of selected } \\
\text { areas of company's activity. }\end{array}$ & $\begin{array}{l}\text { Used only in certain } \\
\text { situations and specific } \\
\text { sectors of the economy. }\end{array}$ \\
\hline
\end{tabular}

All the methods given in the table are actively used to evaluate digital transformation projects in Western companies and some Russian firms. According to the research "IT in Russian enterprises: practice and perspectives" about $26 \%$ of companies use quantitative methods to evaluate developments in the field of digital technologies. At the same time, more than $60 \%$ of Russian companies use qualitative methods (Shebzukhov, 2016).

There are a sufficiently large number of methods for assessing the effectiveness of digital transformation, but no one universal method, the use of which in most cases would give a reliable result, can be distinguished. It should also be remembered that without taking into account the characteristics of the company and the market in which it operates (in our case - the emerging market), the use of any technique is at least incorrect.

Development of a methodology for assessing the economic efficiency of company digital transformation

The main idea of the integrated methodology for evaluating the effectiveness of company digital transformation, which is proposed by the author of the article, is the simultaneous combination of two approaches to evaluation: quantitative and qualitative. The mandatory application of the two approaches will make it possible to assess the benefits that the company receives from the digital transformation in quantitative terms.

A qualitative approach is used to assess the benefits that the company should acquire in the process of implementing the project. It also allows comparing the state of the company's business processes before and after the project implementation, as well as after two years of the company's activity in the new conditions, and in creating a forecast of the necessary costs for the project (Strauss, Corbin, 2008). Moreover, there is an opportunity and a need to compare the changes in the digital transformation process with several companies in the industry, and, when there is no such opportunity, with foreign firms that work in the same market sector.

It should be noted that in Russia, it is necessary to apply foreign experience in the field of qualitative approach with extreme caution. The fact is that digital transformation, for example, in Western countries, most often fully meets two necessary conditions (Zakharchenko, 2016):

1. The replacement of obsolete technologies with new ones is constantly taking place.

2. The company operates in a sustainable market.

From this, it follows that Russian companies are now operating in conditions that are often significantly different from the conditions in which foreign companies operate. When making a decision on digital transformation, the experience of Western companies without taking into account Russian realities cannot be decisive.

The main benefits and advantages to be derived from digitalization are summarized 
in qualitative approach. After that, they are thoroughly analyzed by a group of competent experts representing the key company's Departments (HR, Finance, Production, IT). The result of the analytical work of this group will be a set of ratings that will show the advantages of company digital transformation (in subsystems and in the company as a whole).

The qualitative approach of the integrated method consists of three main stages:

- collection of information on the subject of the analysis;

- processing of all information, analytics, conclusions;

- decision-making based on the results of the first two stages and the results of the quantitative approach.

Information is collected using a variety of expert methods (questioning, observation, interviewing). Then information processing methods are used (normal rank, determining the weights and comparisons in a strict sequence). To make a decision, within the framework of the integrated method and its qualitative approach, it is necessary to use a number of other methods: heuristic, statistical, analytical methods which give good results, etc.

It is advisable to use the quantitative approach for the investment analysis of company digital transformation projects (according to the traditional standard techniques). In this study, the most important is to determine the expenditure side of the project and the benefits that have already been obtained. The result of the quantitative approach to project effectiveness evaluation will be generally accepted indicators of investment analysis (payback period, NPV, IRR).

Fig. 1 presents quantitative approach to evaluate the effectiveness of digital transformation.

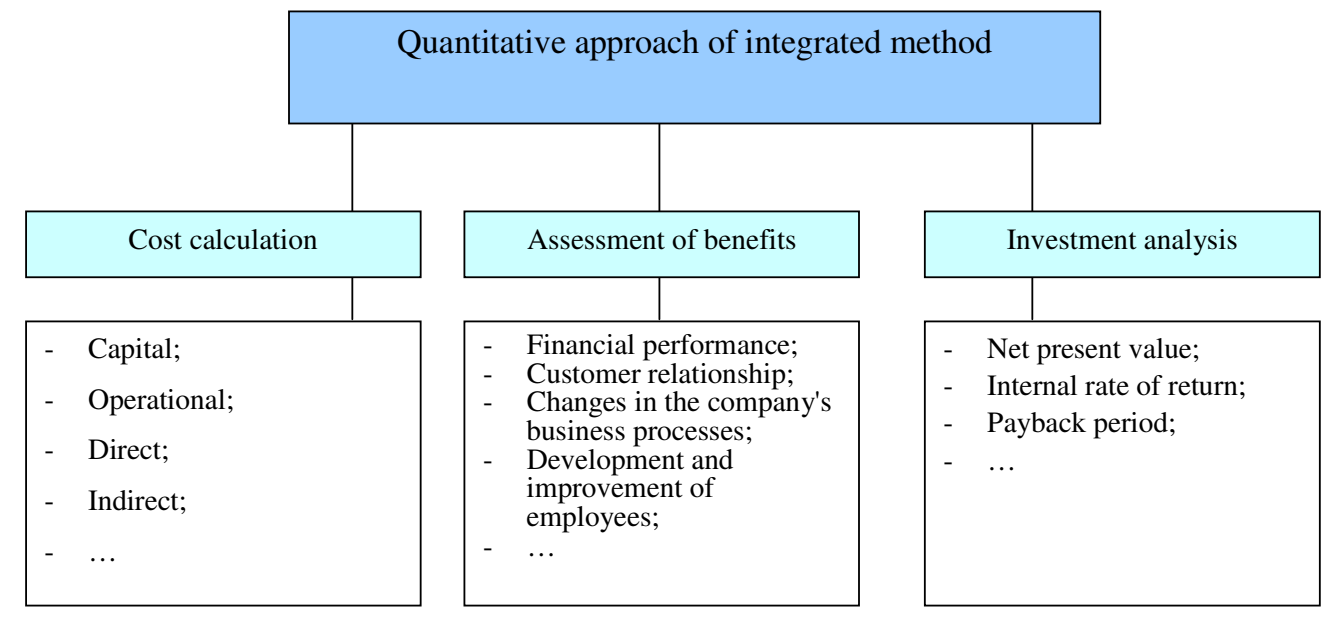

Fig. 1: The scheme of quantitative approach to the evaluation of digital transformation efficiency

Total cost of ownership (TCO) can be used to estimate a project costs (Berg et al, 2016).

The advantages and benefits of the project can be assessed using the balanced scorecard methodology, if it is already established in the company.

A generalized scheme of the integrated method used to evaluate the effectiveness of digital transformation is shown in Fig. 2. 


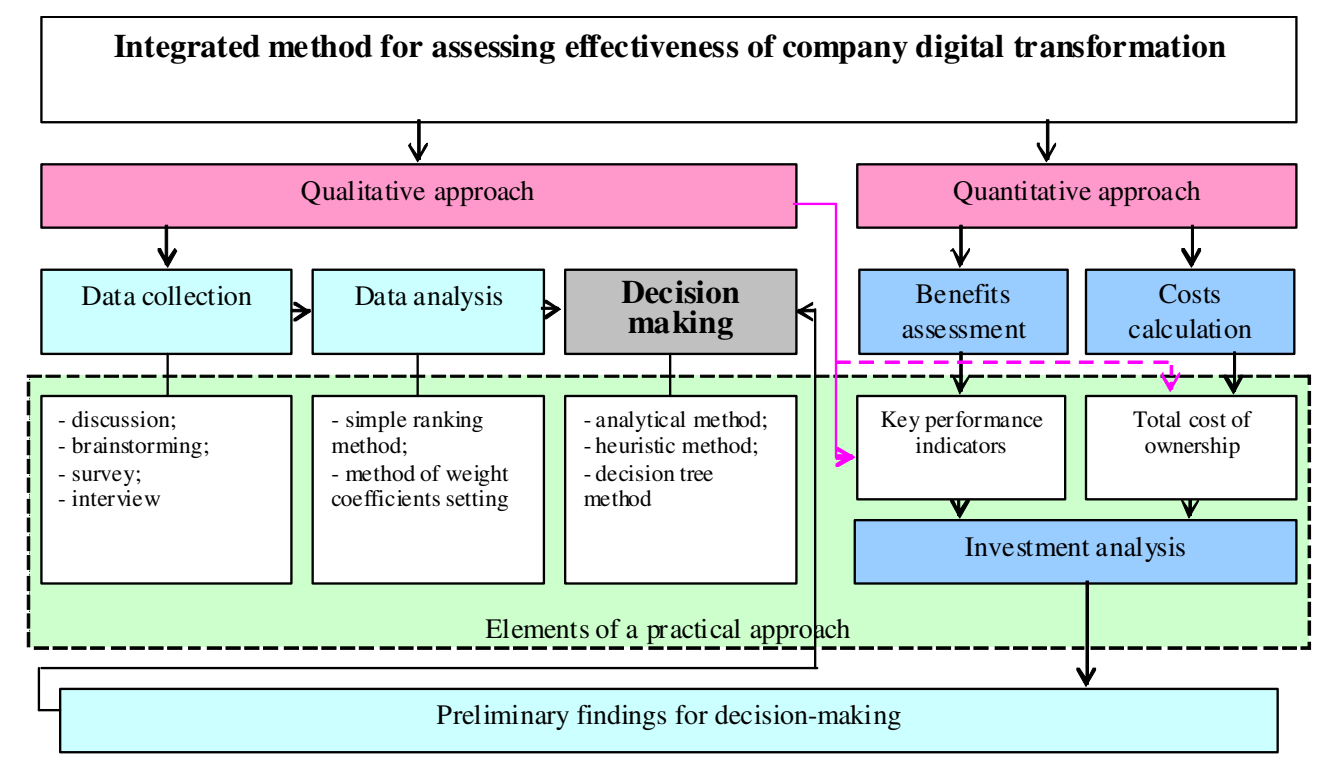

Fig. 2: The generalized scheme of integrated method

In order to better understand all the possibilities of the integrated method, it is necessary to clarify its place among all the methods of evaluating digital transformation effectiveness. This method is a synthesis of two approaches: quantitative and qualitative. This fact already makes this method distinguishable from the others. As part of the performance assessment process, this methodology is based on already established approaches, such as a balanced scorecard and TCO. In this regard, it exists in close relationship with other methods. However, it can not be put on a par with other techniques, as it is aimed at solving a specific problem.

The integrated method of assessing digital transformation economic efficiency was approbated at the Russian company "Grafika", specializing in the production of printed products: printed materials and packaging.

The management of "Grafika" made the decision to implement a project of complex business digitalization. The task of qualitative improvement of business efficiency, the requirements for the functionality of information support, and system-wide requirements necessitate digital transformation on the basis of ERP platform. The choice was made in favor of Oracle ERP-solutions. It is planned to create an integrated digital management system that combines information used by numerous functional units and branches into a unified system.

In accordance with the developed methodology, the basis for assessing was qualitative and quantitative approaches used in combination. The results of the qualitative approach were key performance indicators (KPIs). KPIs were further used in the investment analysis as part of the quantitative approach. In addition to the investment analysis, the quantitative approach included the forecast of the project costs (TCO), as well as the assessment of changes in more qualitative performance indicators in quantitative terms.

The basis of the qualitative approach was the activity of the expert group (implementation group), which included representatives of the main company's divisions.

As part of the qualitative approach, several meetings of the working group were held. At these meetings, participants were given information materials about the project. 
These materials were the subject of careful study and the basis for the subsequent development of KPIs.

At the meetings of the working group, the main goals and tasks that need to be implemented in the process of digital transformation were elaborated.

Questioning of employees was carried out in several stages. After each stage, the data were subjected to careful analysis and discussion of the dedicated team of employees then formed the questions in the following questionnaire.

One of the main results of applying the qualitative approach was the developed system of indicators, expert assessments of the importance of each indicator, as well as possible changes in the developed performance indicators as a result of the project implementation.

The developed system of KPIs, their importance and their planned changes are shown in Appendix 1.

The basis of the quantitative approach of the integrated method is the consideration of the "Grafika" digital transformation as an investment project. In this case, the following values must be defined:

- $\quad$ capital costs of the project;

- $\quad$ current costs, both direct and indirect;

- benefits from the introduction of the system (in cash).

The above values are used to calculate effectiveness indicators of the project (net present value, internal rate of return, payback period).

To determine the cost of the digital transformation project, "Grafika" used TCO methodology, which allows taking into account both direct and indirect costs.

The list of the main costs and their distribution by months of the project are reflected in Appendix 2.
As noted earlier, the benefits of the project are determined using balanced scorecard approach. KPIs were developed as part of qualitative approach. Within the framework of the quantitative methodology, the qualitative indicators were evaluated in cash. To do this, expert approach was used. The assessment was made by group of representatives of the Financial and Economic Department.

It should be noted that the scheme of practical application of the integrated assessment method in "Grafika" is not a standard, but can be used in other companies in Russia and other countries. When evaluating digitalization according to this method, it is necessary to remember that its simplification inevitably leads to a decrease in the accuracy of the results, and excessive complication does not always lead to the same increase in accuracy.

To substantiate the advantages and benefits derived from the project, the balanced scorecard methodology was used. In developing the KPIs, the team of "Grafika" experts focused on the tactical objectives of digital transformation, namely (in accordance with four perspectives):

- $\quad$ reducing the customer service time;

- reducing the cost of servicing one customer;

- $\quad$ change of business processes;

- improvement of knowledge and skills of the company's employees.

As a result of the work carried out to reflect the tactical goals of the company in the system of key performance indicators, twenty performance indicators (five for each perspective) were formed, which is enough to build a pilot model.

The qualitative indicators reflected in Appendix 3 were evaluated in cash using an expert approach.

Substantiation of the effectiveness of the digital transformation project in "Grafika" in the framework of the integrated method 
was carried out using techniques and methods of investment analysis.

Within the framework of the project, taking into account the wishes of the investor, the three years (thirty-six months) horizon of calculation was chosen.

Microsoft Excel was used to analyze the investment efficiency of "Grafika" digital transformation.

A number of calculations were carried out, the results of which are as follows:

- the digital transformation project can be considered economically justified, since the payback period does not exceed three years acceptable for the company (it is thirty-five months twenty-nine days);

- the project is characterized by significant sensitivity to changes in some of its parameters, for example, discount rates, expert evaluation of benefits and advantages (in monetary terms);

- the NPV shows the cost nature of the project and the greater difficulty in making a profit from digitalization by increasing the cost of the project or reducing the expected profit.

The results of the investment analysis are presented in Appendix 4.

Expert assessment of the possibilities of business digitalization (qualitative approach), as well as taking into account the experience of companies in other industries revealed the following:

- digital transformation allows improving the quality of customer service, significantly reducing the time spent by managers and customers of the company "Grafika" on the process of primary and subsequent service;

- the time spent by employees of "Grafika" divisions engaged in the provision of additional customer services is reduced);
- there is an opportunity to implement the concept of electronic document management, which reduces the company's costs for various items;

- digitalization allows employees to develop their skills and knowledge much faster;

- digitalization has a positive impact on the company's business processes, with stimulating measures to improve them;

- digital transformation may not bring the expected amount of benefits and advantages in monetary terms (due to the low speed of implementation of information systems, the speed of changes in the company's business processes, as well as due to the inaccuracy of expert estimates obtained in the framework of the balanced scorecard methodology application).

Changes in the key performance indicators developed as part of a qualitative approach to assessing the effectiveness of digital transformation are reflected in Appendix 5.

The synthesis of the results of qualitative (identified advantages of digitalization) and quantitative (payback of the project within three years) approaches made it possible to make an informed decision on the feasibility of "Grafika" digital transformation.

\section{Conclusion}

The author has developed integrated method of evaluating the effectiveness of company digital transformation. The method takes into account direct (software and hardware, operation, training) and indirect (self- and mutual support of users, their downtime) costs, as well as key performance indicators. The algorithm of decision-making on digital transformation, which is an integral part of the methodology, is based on the evaluation of the results of the investment analysis of costs and benefits of the project, as well as 
expert evaluation of the benefits of the project.

The main idea of the proposed method is a mandatory combination of two approaches to evaluation: qualitative and quantitative. The use of two approaches will allow quantifying the benefits of digital transformation.

The application of the method in one of the Russian companies met all the expectations of its developer: the method allowed evaluating the project and making a decision on its implementation.

At present, the importance of the integrated method for evaluating the effectiveness of digital transformation is quite difficult to determine. Until such time as the integrated method will not be repeatedly used in practice and until the assessment of results reliability from its application is made, it is not correct to speak about its importance.

This method can be used at different levels of the company, whether it is the main subsystems or their associations, as well as the company as a whole. However, this requires some changes. Moreover, it is possible to use the method at any stage of digital transformation.

\section{References}

1. Andriole, S. J. (2017) 'Five Myths About Digital Transformation,' MIT Sloan Management Review (Reprint \#58317), 1-6.

2. Berg, T., Kirwin, W., Redman, B. (2016) 'TCO: a critical Tool for Measuring IT,' Gartner Advisory Strategic Analysis Report, 12-10.

3. Early, S. (2014) 'The Digital Transformation: Staying Competitive,' IT Professional, 58-60.

4. Shebzukhov, A. (2016) 'The Development of information technologies: status and prospects,' Scientific-methodical electronic journal 'Concept', 59(3), 23-31.

5. Strauss, A., \& Corbin, J. (2008) Basics of Qualitative Research: Grounded Theory Procedures and Techniques (3rd edition ed.), Newbury Park, CA: Sage Publications Ltd.

6. Westerman, G., \& Bonnet, D. (2015) 'Revamping Your Business Through Digital Transformation,' MIT Sloan Management Review, 1-5.

7. Zakharchenko, D. (2016) 'Digital technologies as a factor of infrastructure development of modern economy,' Economic Sciences, 7(92), 43-49. 


\section{Appendix 1}

Table 1: KPIs changes - "Finance" perspective

\begin{tabular}{|c|c|c|c|c|c|}
\hline \multirow[b]{2}{*}{ Month } & \multicolumn{3}{|c|}{ Reducing costs } & \multicolumn{2}{|c|}{ Profit growth due to } \\
\hline & $\begin{array}{c}\text { Communication } \\
\text { tools, } \%\end{array}$ & $\begin{array}{c}\text { Contractual } \\
\text { and claims } \\
\text { activities, } \%\end{array}$ & $\begin{array}{c}\text { Customer } \\
\text { service } \\
\text { activities, \% }\end{array}$ & $\begin{array}{c}\text { The provision } \\
\text { of additional } \\
\text { services, } \%\end{array}$ & $\begin{array}{l}\text { Improving the } \\
\text { quality of } \\
\text { customer } \\
\text { service, } \%\end{array}$ \\
\hline 1 & $0.00 \%$ & $0.00 \%$ & $0.00 \%$ & $0.00 \%$ & $0.00 \%$ \\
\hline 2 & $0.00 \%$ & $0.00 \%$ & $0.00 \%$ & $0.00 \%$ & $0.00 \%$ \\
\hline 3 & $0.00 \%$ & $0.00 \%$ & $0.00 \%$ & $0.00 \%$ & $0.00 \%$ \\
\hline 4 & $0.00 \%$ & $0.00 \%$ & $0.00 \%$ & $0.00 \%$ & $0.00 \%$ \\
\hline 5 & $0.00 \%$ & $0.00 \%$ & $0.00 \%$ & $0.00 \%$ & $0.00 \%$ \\
\hline 6 & $0.00 \%$ & $0.00 \%$ & $0.00 \%$ & $0.00 \%$ & $0.00 \%$ \\
\hline 7 & $1.47 \%$ & $1.59 \%$ & $1.71 \%$ & $1.00 \%$ & $0.71 \%$ \\
\hline 8 & $2.94 \%$ & $3.18 \%$ & $3.41 \%$ & $2.00 \%$ & $1.41 \%$ \\
\hline 9 & $4.41 \%$ & $4.76 \%$ & $5.12 \%$ & $3.00 \%$ & $2.12 \%$ \\
\hline 10 & $5.88 \%$ & $6.35 \%$ & $6.82 \%$ & $4.00 \%$ & $2.82 \%$ \\
\hline 11 & $8.82 \%$ & $9.53 \%$ & $10.24 \%$ & $6.00 \%$ & $4.24 \%$ \\
\hline 12 & $11.76 \%$ & $12.71 \%$ & $13.65 \%$ & $8.00 \%$ & $5.65 \%$ \\
\hline 13 & $14.71 \%$ & $15.88 \%$ & $17.06 \%$ & $10.00 \%$ & $7.06 \%$ \\
\hline 14 & $17.65 \%$ & $19.06 \%$ & $20.47 \%$ & $12.00 \%$ & $8.47 \%$ \\
\hline 15 & $22.06 \%$ & $23.82 \%$ & $25.59 \%$ & $15.00 \%$ & $10.59 \%$ \\
\hline 16 & $23.53 \%$ & $25.41 \%$ & $27.29 \%$ & $16.00 \%$ & $11.29 \%$ \\
\hline 17 & $23.53 \%$ & $25.41 \%$ & $27.29 \%$ & $16.00 \%$ & $11.29 \%$ \\
\hline 18 & $23.53 \%$ & $25.41 \%$ & $27.29 \%$ & $16.00 \%$ & $11.29 \%$ \\
\hline 19 & $23.53 \%$ & $25.41 \%$ & $27.29 \%$ & $16.00 \%$ & $11.29 \%$ \\
\hline 20 & $23.53 \%$ & $25.41 \%$ & $27.29 \%$ & $16.00 \%$ & $11.29 \%$ \\
\hline 21 & $23.53 \%$ & $25.41 \%$ & $27.29 \%$ & $16.00 \%$ & $11.29 \%$ \\
\hline 22 & $23.53 \%$ & $25.41 \%$ & $27.29 \%$ & $16.00 \%$ & $11.29 \%$ \\
\hline 23 & $24.26 \%$ & $26.21 \%$ & $28.15 \%$ & $16.50 \%$ & $11.65 \%$ \\
\hline 24 & $24.26 \%$ & $26.21 \%$ & $28.15 \%$ & $16.50 \%$ & $11.65 \%$ \\
\hline 25 & $24.26 \%$ & $26.21 \%$ & $28.15 \%$ & $16.50 \%$ & $11.65 \%$ \\
\hline 26 & $24.26 \%$ & $26.21 \%$ & $28.15 \%$ & $16.50 \%$ & $11.65 \%$ \\
\hline 27 & $24.26 \%$ & $26.21 \%$ & $28.15 \%$ & $16.50 \%$ & $11.65 \%$ \\
\hline 28 & $24.26 \%$ & $26.21 \%$ & $28.15 \%$ & $16.50 \%$ & $11.65 \%$ \\
\hline 29 & $24.26 \%$ & $26.21 \%$ & $28.15 \%$ & $16.50 \%$ & $11.65 \%$ \\
\hline 30 & $24.26 \%$ & $26.21 \%$ & $28.15 \%$ & $16.50 \%$ & $11.65 \%$ \\
\hline 31 & $24.26 \%$ & $26.21 \%$ & $28.15 \%$ & $16.50 \%$ & $11.65 \%$ \\
\hline 32 & $24.26 \%$ & $26.21 \%$ & $28.15 \%$ & $16.50 \%$ & $11.65 \%$ \\
\hline 33 & $25.00 \%$ & $27.00 \%$ & $29.00 \%$ & $17.00 \%$ & $12.00 \%$ \\
\hline 34 & $25.00 \%$ & $27.00 \%$ & $29.00 \%$ & $17.00 \%$ & $12.00 \%$ \\
\hline 35 & $25.00 \%$ & $27.00 \%$ & $29.00 \%$ & $17.00 \%$ & $12.00 \%$ \\
\hline
\end{tabular}

Alexander KUNTSMAN and Igor Anatolevich ARENKOV (2019), IBIMA Business Review, 


\begin{tabular}{|c|c|c|c|c|c|}
\hline 36 & $25.00 \%$ & $27.00 \%$ & $29.00 \%$ & $17.00 \%$ & $12.00 \%$ \\
\hline
\end{tabular}

Table 2: KPIs changes - "Clients" perspective

\begin{tabular}{|c|c|c|c|c|c|}
\hline \multirow[b]{2}{*}{ Month } & \multicolumn{3}{|c|}{ Reducing costs } & \multicolumn{2}{|c|}{ Profit growth due to } \\
\hline & $\begin{array}{l}\text { Reducing the } \\
\text { amount of } \\
\text { primary } \\
\text { service time, } \\
\%\end{array}$ & $\begin{array}{c}\text { Reduce the } \\
\text { time of } \\
\text { periodic } \\
\text { service, } \%\end{array}$ & $\begin{array}{c}\text { Reduce } \\
\text { document } \\
\text { preparation } \\
\text { time, } \%\end{array}$ & $\begin{array}{l}\text { Increasing the } \\
\text { need for } \\
\text { existing } \\
\text { services, } \\
\text { attracting new } \\
\text { customers, \% }\end{array}$ & $\begin{array}{c}\text { Customer } \\
\text { satisfaction } \\
\text { increase, \% }\end{array}$ \\
\hline 1 & $0.00 \%$ & $0.00 \%$ & $0.00 \%$ & $0.00 \%$ & $0.00 \%$ \\
\hline 2 & $0.00 \%$ & $0.00 \%$ & $0.00 \%$ & $0.00 \%$ & $0.00 \%$ \\
\hline 3 & $0.00 \%$ & $0.00 \%$ & $0.00 \%$ & $0.00 \%$ & $0.00 \%$ \\
\hline 4 & $0.00 \%$ & $0.00 \%$ & $0.00 \%$ & $0.00 \%$ & $0.00 \%$ \\
\hline 5 & $0.00 \%$ & $0.00 \%$ & $0.00 \%$ & $0.00 \%$ & $0.00 \%$ \\
\hline 6 & $0.00 \%$ & $0.00 \%$ & $0.00 \%$ & $0.00 \%$ & $0.00 \%$ \\
\hline 7 & $1.51 \%$ & $2.00 \%$ & $2.24 \%$ & $1.39 \%$ & $1.67 \%$ \\
\hline 8 & $3.02 \%$ & $4.00 \%$ & $4.49 \%$ & $2.78 \%$ & $3.35 \%$ \\
\hline 9 & $5.29 \%$ & $7.00 \%$ & $7.86 \%$ & $4.86 \%$ & $5.86 \%$ \\
\hline 10 & $7.55 \%$ & $10.00 \%$ & $11.22 \%$ & $6.94 \%$ & $8.37 \%$ \\
\hline 11 & $11.33 \%$ & $15.00 \%$ & $16.84 \%$ & $10.41 \%$ & $12.55 \%$ \\
\hline 12 & $15.10 \%$ & $20.00 \%$ & $22.45 \%$ & $13.88 \%$ & $16.73 \%$ \\
\hline 13 & $19.63 \%$ & $26.00 \%$ & $29.18 \%$ & $18.04 \%$ & $21.76 \%$ \\
\hline 14 & $24.16 \%$ & $32.00 \%$ & $35.92 \%$ & $22.20 \%$ & $26.78 \%$ \\
\hline 15 & $26.43 \%$ & $35.00 \%$ & $39.29 \%$ & $24.29 \%$ & $29.29 \%$ \\
\hline 16 & $28.69 \%$ & $38.00 \%$ & $42.65 \%$ & $26.37 \%$ & $31.80 \%$ \\
\hline 17 & $30.96 \%$ & $41.00 \%$ & $46.02 \%$ & $28.45 \%$ & $34.31 \%$ \\
\hline 18 & $32.47 \%$ & $43.00 \%$ & $48.27 \%$ & $29.84 \%$ & $35.98 \%$ \\
\hline 19 & $33.22 \%$ & $44.00 \%$ & $49.39 \%$ & $30.53 \%$ & $36.82 \%$ \\
\hline 20 & $33.98 \%$ & $45.00 \%$ & $50.51 \%$ & $31.22 \%$ & $37.65 \%$ \\
\hline 21 & $33.98 \%$ & $45.00 \%$ & $50.51 \%$ & $31.22 \%$ & $37.65 \%$ \\
\hline 22 & $34.73 \%$ & $46.00 \%$ & $51.63 \%$ & $31.92 \%$ & $38.49 \%$ \\
\hline 23 & $34.73 \%$ & $46.00 \%$ & $51.63 \%$ & $31.92 \%$ & $38.49 \%$ \\
\hline 24 & $34.73 \%$ & $46.00 \%$ & $51.63 \%$ & $31.92 \%$ & $38.49 \%$ \\
\hline 25 & $35.49 \%$ & $47.00 \%$ & $52.76 \%$ & $32.61 \%$ & $39.33 \%$ \\
\hline 26 & $35.49 \%$ & $47.00 \%$ & $52.76 \%$ & $32.61 \%$ & $39.33 \%$ \\
\hline 27 & $35.49 \%$ & $47.00 \%$ & $52.76 \%$ & $32.61 \%$ & $39.33 \%$ \\
\hline 28 & $35.49 \%$ & $47.00 \%$ & $52.76 \%$ & $32.61 \%$ & $39.33 \%$ \\
\hline 29 & $35.49 \%$ & $47.00 \%$ & $52.76 \%$ & $32.61 \%$ & $39.33 \%$ \\
\hline 30 & $36.24 \%$ & $48.00 \%$ & $53.88 \%$ & $33.31 \%$ & $40.16 \%$ \\
\hline 31 & $36.24 \%$ & $48.00 \%$ & $53.88 \%$ & $33.31 \%$ & $40.16 \%$ \\
\hline 32 & $36.24 \%$ & $48.00 \%$ & $53.88 \%$ & $33.31 \%$ & $40.16 \%$ \\
\hline
\end{tabular}

Alexander KUNTSMAN and Igor Anatolevich ARENKOV (2019), IBIMA Business Review, 


\begin{tabular}{|l|l|l|l|l|l|}
\hline 33 & $36.24 \%$ & $48.00 \%$ & $53.88 \%$ & $33.31 \%$ & $40.16 \%$ \\
\hline 34 & $36.24 \%$ & $48.00 \%$ & $53.88 \%$ & $33.31 \%$ & $40.16 \%$ \\
\hline 35 & $37.00 \%$ & $49.00 \%$ & $55.00 \%$ & $34.00 \%$ & $41.00 \%$ \\
\hline 36 & $37.00 \%$ & $49.00 \%$ & $55.00 \%$ & $34.00 \%$ & $41.00 \%$ \\
\hline
\end{tabular}

Table 3: KPIs changes - "Business processes" perspective

\begin{tabular}{|c|c|c|c|c|c|}
\hline \multirow[b]{2}{*}{ Month } & \multicolumn{3}{|c|}{ Reducing costs } & \multicolumn{2}{|c|}{ Profit growth due to } \\
\hline & $\begin{array}{c}\text { Internal } \\
\text { document } \\
\text { circulation, } \%\end{array}$ & $\begin{array}{c}\text { Periodic forced } \\
\text { improvement of } \\
\text { business } \\
\text { processes, } \%\end{array}$ & $\begin{array}{l}\text { Overcoming } \\
\text { employee } \\
\text { resistance to } \\
\text { change, \% }\end{array}$ & $\begin{array}{c}\text { Reducing the } \\
\text { inertia of } \\
\text { business } \\
\text { processes, \% }\end{array}$ & $\begin{array}{c}\text { Overall } \\
\text { improvement of } \\
\text { business } \\
\text { processes in the } \\
\text { direction of } \\
\text { reliability, \% }\end{array}$ \\
\hline 1 & $0.00 \%$ & $0.00 \%$ & $0.00 \%$ & $0.00 \%$ & $0.00 \%$ \\
\hline 2 & $0.00 \%$ & $0.00 \%$ & $0.00 \%$ & $0.00 \%$ & $0.00 \%$ \\
\hline 3 & $0.00 \%$ & $0.00 \%$ & $0.00 \%$ & $0.00 \%$ & $0.00 \%$ \\
\hline 4 & $0.00 \%$ & $0.00 \%$ & $0.00 \%$ & $0.00 \%$ & $0.00 \%$ \\
\hline 5 & $0.00 \%$ & $0.00 \%$ & $0.00 \%$ & $0.00 \%$ & $0.00 \%$ \\
\hline 6 & $0.00 \%$ & $0.00 \%$ & $0.00 \%$ & $0.00 \%$ & $0.00 \%$ \\
\hline 7 & $1.00 \%$ & $0.47 \%$ & $0.35 \%$ & $0.68 \%$ & $0.65 \%$ \\
\hline 8 & $3.00 \%$ & $1.41 \%$ & $1.06 \%$ & $2.03 \%$ & $1.94 \%$ \\
\hline 9 & $6.00 \%$ & $2.82 \%$ & $2.12 \%$ & $4.06 \%$ & $3.88 \%$ \\
\hline 10 & $10.00 \%$ & $4.71 \%$ & $3.53 \%$ & $6.76 \%$ & $6.47 \%$ \\
\hline 11 & $14.00 \%$ & $6.59 \%$ & $4.94 \%$ & $9.47 \%$ & $9.06 \%$ \\
\hline 12 & $18.00 \%$ & $8.47 \%$ & $6.35 \%$ & $12.18 \%$ & $11.65 \%$ \\
\hline 13 & $21.00 \%$ & $9.88 \%$ & $7.41 \%$ & $14.21 \%$ & $13.59 \%$ \\
\hline 14 & $22.00 \%$ & $10.35 \%$ & $7.76 \%$ & $14.88 \%$ & $14.24 \%$ \\
\hline 15 & $23.00 \%$ & $10.82 \%$ & $8.12 \%$ & $15.56 \%$ & $14.88 \%$ \\
\hline 16 & $24.00 \%$ & $11.29 \%$ & $8.47 \%$ & $16.24 \%$ & $15.53 \%$ \\
\hline 17 & $25.00 \%$ & $11.76 \%$ & $8.82 \%$ & $16.91 \%$ & $16.18 \%$ \\
\hline 18 & $26.00 \%$ & $12.24 \%$ & $9.18 \%$ & $17.59 \%$ & $16.82 \%$ \\
\hline 19 & $27.00 \%$ & $12.71 \%$ & $9.53 \%$ & $18.26 \%$ & $17.47 \%$ \\
\hline 20 & $28.00 \%$ & $13.18 \%$ & $9.88 \%$ & $18.94 \%$ & $18.12 \%$ \\
\hline 21 & $29.00 \%$ & $13.65 \%$ & $10.24 \%$ & $19.62 \%$ & $18.76 \%$ \\
\hline 22 & $29.00 \%$ & $13.65 \%$ & $10.24 \%$ & $19.62 \%$ & $18.76 \%$ \\
\hline 23 & $30.00 \%$ & $14.12 \%$ & $10.59 \%$ & $20.29 \%$ & $19.41 \%$ \\
\hline 24 & $30.00 \%$ & $14.12 \%$ & $10.59 \%$ & $20.29 \%$ & $19.41 \%$ \\
\hline 25 & $30.00 \%$ & $14.12 \%$ & $10.59 \%$ & $20.29 \%$ & $19.41 \%$ \\
\hline 26 & $31.00 \%$ & $14.59 \%$ & $10.94 \%$ & $20.97 \%$ & $20.06 \%$ \\
\hline 27 & $31.00 \%$ & $14.59 \%$ & $10.94 \%$ & $20.97 \%$ & $20.06 \%$ \\
\hline 28 & $31.00 \%$ & $14.59 \%$ & $10.94 \%$ & $20.97 \%$ & $20.06 \%$ \\
\hline 29 & $32.00 \%$ & $15.06 \%$ & $11.29 \%$ & $21.65 \%$ & $20.71 \%$ \\
\hline
\end{tabular}

Alexander KUNTSMAN and Igor Anatolevich ARENKOV (2019), IBIMA Business Review, DOI: $10.5171 / 2019.334457$ 


\begin{tabular}{|l|l|l|l|l|l|}
\hline 30 & $32.00 \%$ & $15.06 \%$ & $11.29 \%$ & $21.65 \%$ & $20.71 \%$ \\
\hline 31 & $32.00 \%$ & $15.06 \%$ & $11.29 \%$ & $21.65 \%$ & $20.71 \%$ \\
\hline 32 & $33.00 \%$ & $15.53 \%$ & $11.65 \%$ & $22.32 \%$ & $21.35 \%$ \\
\hline 33 & $33.00 \%$ & $15.53 \%$ & $11.65 \%$ & $22.32 \%$ & $21.35 \%$ \\
\hline 34 & $33.00 \%$ & $15.53 \%$ & $11.65 \%$ & $22.32 \%$ & $21.35 \%$ \\
\hline 35 & $33.00 \%$ & $15.53 \%$ & $11.65 \%$ & $22.32 \%$ & $21.35 \%$ \\
\hline 36 & $34.00 \%$ & $16.00 \%$ & $12.00 \%$ & $23.00 \%$ & $22.00 \%$ \\
\hline
\end{tabular}

Table 4: KPIs changes - "Employees" perspective

\begin{tabular}{|c|c|c|c|c|c|}
\hline \multirow[b]{2}{*}{ Month } & \multicolumn{3}{|c|}{ Reducing costs } & \multicolumn{2}{|c|}{ Profit growth due to } \\
\hline & $\begin{array}{l}\text { Improvement of } \\
\text { staff training in } \\
\text { the field of IT, \% }\end{array}$ & $\begin{array}{c}\text { Training of } \\
\text { employees in } \\
\text { modern } \\
\text { methods of } \\
\text { work with } \\
\text { clients, \% }\end{array}$ & $\begin{array}{c}\text { Retention or } \\
\text { training of } \\
\text { key } \\
\text { employees of } \\
\text { the company, } \\
\%\end{array}$ & $\begin{array}{c}\text { Improving } \\
\text { employees' } \\
\text { ability to work } \\
\text { with clients, \% }\end{array}$ & $\begin{array}{c}\text { General } \\
\text { increase of } \\
\text { social } \\
\text { responsibility of } \\
\text { employees, \% }\end{array}$ \\
\hline 1 & $0.00 \%$ & $0.00 \%$ & $0.00 \%$ & $0.00 \%$ & $0.00 \%$ \\
\hline 2 & $0.00 \%$ & $0.00 \%$ & $0.00 \%$ & $0.00 \%$ & $0.00 \%$ \\
\hline 3 & $0.00 \%$ & $0.00 \%$ & $0.00 \%$ & $0.00 \%$ & $0.00 \%$ \\
\hline 4 & $0.00 \%$ & $0.00 \%$ & $0.00 \%$ & $0.00 \%$ & $0.00 \%$ \\
\hline 5 & $0.00 \%$ & $0.00 \%$ & $0.00 \%$ & $0.00 \%$ & $0.00 \%$ \\
\hline 6 & $0.00 \%$ & $0.00 \%$ & $0.00 \%$ & $0.00 \%$ & $0.00 \%$ \\
\hline 7 & $1.17 \%$ & $2.00 \%$ & $2.76 \%$ & $1.93 \%$ & $1.79 \%$ \\
\hline 8 & $1.47 \%$ & $2.50 \%$ & $3.45 \%$ & $2.41 \%$ & $2.24 \%$ \\
\hline 9 & $1.76 \%$ & $3.00 \%$ & $4.14 \%$ & $2.90 \%$ & $2.69 \%$ \\
\hline 10 & $2.05 \%$ & $3.50 \%$ & $4.83 \%$ & $3.38 \%$ & $3.14 \%$ \\
\hline 11 & $2.34 \%$ & $4.00 \%$ & $5.52 \%$ & $3.86 \%$ & $3.59 \%$ \\
\hline 12 & $2.93 \%$ & $5.00 \%$ & $6.90 \%$ & $4.83 \%$ & $4.48 \%$ \\
\hline 13 & $3.52 \%$ & $6.00 \%$ & $8.28 \%$ & $5.79 \%$ & $5.38 \%$ \\
\hline 14 & $4.10 \%$ & $7.00 \%$ & $9.66 \%$ & $6.76 \%$ & $6.28 \%$ \\
\hline 15 & $5.28 \%$ & $9.00 \%$ & $12.41 \%$ & $8.69 \%$ & $8.07 \%$ \\
\hline 16 & $7.03 \%$ & $12.00 \%$ & $16.55 \%$ & $11.59 \%$ & $10.76 \%$ \\
\hline 17 & $9.38 \%$ & $16.00 \%$ & $22.07 \%$ & $15.45 \%$ & $14.34 \%$ \\
\hline 18 & $12.90 \%$ & $22.00 \%$ & $30.34 \%$ & $21.24 \%$ & $19.72 \%$ \\
\hline 19 & $14.07 \%$ & $24.00 \%$ & $33.10 \%$ & $23.17 \%$ & $21.52 \%$ \\
\hline 20 & $14.95 \%$ & $25.50 \%$ & $35.17 \%$ & $24.62 \%$ & $22.86 \%$ \\
\hline 21 & $15.24 \%$ & $26.00 \%$ & $35.86 \%$ & $25.10 \%$ & $23.31 \%$ \\
\hline 22 & $15.83 \%$ & $27.00 \%$ & $37.24 \%$ & $26.07 \%$ & $24.21 \%$ \\
\hline 23 & $15.83 \%$ & $27.00 \%$ & $37.24 \%$ & $26.07 \%$ & $24.21 \%$ \\
\hline 24 & $15.83 \%$ & $27.00 \%$ & $37.24 \%$ & $26.07 \%$ & $24.21 \%$ \\
\hline 25 & $16.41 \%$ & $28.00 \%$ & $38.62 \%$ & $27.03 \%$ & $25.10 \%$ \\
\hline 26 & $16.41 \%$ & $28.00 \%$ & $38.62 \%$ & $27.03 \%$ & $25.10 \%$ \\
\hline 27 & $16.41 \%$ & $28.00 \%$ & $38.62 \%$ & $27.03 \%$ & $25.10 \%$ \\
\hline
\end{tabular}




\begin{tabular}{|l|l|l|l|l|l|}
\hline 28 & $16.41 \%$ & $28.00 \%$ & $38.62 \%$ & $27.03 \%$ & $25.10 \%$ \\
\hline 29 & $16.41 \%$ & $28.00 \%$ & $38.62 \%$ & $27.03 \%$ & $25.10 \%$ \\
\hline 30 & $16.71 \%$ & $28.50 \%$ & $39.31 \%$ & $27.52 \%$ & $25.55 \%$ \\
\hline 31 & $16.71 \%$ & $28.50 \%$ & $39.31 \%$ & $27.52 \%$ & $25.55 \%$ \\
\hline 32 & $16.71 \%$ & $28.50 \%$ & $39.31 \%$ & $27.52 \%$ & $25.55 \%$ \\
\hline 33 & $16.71 \%$ & $28.50 \%$ & $39.31 \%$ & $27.52 \%$ & $25.55 \%$ \\
\hline 34 & $16.71 \%$ & $28.50 \%$ & $39.31 \%$ & $27.52 \%$ & $25.55 \%$ \\
\hline 35 & $16.71 \%$ & $28.50 \%$ & $39.31 \%$ & $27.52 \%$ & $25.55 \%$ \\
\hline 36 & $17.00 \%$ & $29.00 \%$ & $40.00 \%$ & $28.00 \%$ & $26.00 \%$ \\
\hline
\end{tabular}

\section{Appendix 2}

Table: Costs of digital transformation (TCO)

\begin{tabular}{|c|c|c|c|c|c|c|c|c|c|}
\hline $\begin{array}{c}\text { Mont } \\
\text { h }\end{array}$ & $\begin{array}{c}\text { Hardwar } \\
\text { e and } \\
\text { software }\end{array}$ & $\begin{array}{l}\text { Manageme } \\
\text { nt and staff }\end{array}$ & $\begin{array}{c}\text { Developme } \\
\text { nt }\end{array}$ & $\begin{array}{c}\text { Telecomm } \\
\text { u-nications }\end{array}$ & $\begin{array}{c}\text { TOTAL } \\
\text { Direct } \\
\text { costs }\end{array}$ & $\begin{array}{c}\text { User costs } \\
\text { of digital } \\
\text { technologie } \\
\text { s }\end{array}$ & $\begin{array}{c}\text { Downtim } \\
\text { e }\end{array}$ & $\begin{array}{l}\text { TOTAL } \\
\text { Indirec } \\
\text { t costs }\end{array}$ & $\begin{array}{l}\text { TOTAL } \\
\text { COSTS }\end{array}$ \\
\hline 1 & 36700 & 11925 & 6600 & 0 & 55225 & 0 & 1740 & 1740 & 56965 \\
\hline 2 & 7200 & 40025 & 6600 & 1000 & 54825 & 212 & 15846 & 16058 & 70883 \\
\hline 3 & 5900 & 32538 & 3600 & 1320 & 43358 & 2067 & 9501 & 11568 & 54926 \\
\hline 4 & 11800 & 38366 & 3600 & 1560 & 55326 & 3392 & 15036 & 18428 & 73754 \\
\hline 5 & 5900 & 52366 & 6600 & 1680 & 66546 & 3763 & 24279 & 28042 & 94588 \\
\hline 6 & 0 & 32266 & 3600 & 1680 & 37546 & 4399 & 10707 & 15106 & 52652 \\
\hline 7 & 0 & 32266 & 3600 & 1680 & 37546 & 4399 & 11307 & 15706 & 53252 \\
\hline 8 & 0 & 32266 & 3600 & 1680 & 37546 & 4399 & 11307 & 15706 & 53252 \\
\hline 9 & 0 & 32266 & 3600 & 1680 & 37546 & 4399 & 11307 & 15706 & 53252 \\
\hline 10 & 0 & 32266 & 3600 & 1680 & 37546 & 4399 & 11307 & 15706 & 53252 \\
\hline 11 & 0 & 32266 & 3600 & 1680 & 37546 & 4399 & 11307 & 15706 & 53252 \\
\hline 12 & 0 & 32266 & 3600 & 1680 & 37546 & 4399 & 11307 & 15706 & 53252 \\
\hline 13 & 0 & 32266 & 3600 & 1680 & 37546 & 4399 & 11307 & 15706 & 53252 \\
\hline 14 & 0 & 32266 & 3600 & 1680 & 37546 & 4399 & 11307 & 15706 & 53252 \\
\hline 15 & 0 & 32266 & 3600 & 1680 & 37546 & 4399 & 11307 & 15706 & 53252 \\
\hline 16 & 0 & 32266 & 3600 & 1680 & 37546 & 4399 & 11307 & 15706 & 53252 \\
\hline 17 & 0 & 32266 & 3600 & 1680 & 37546 & 4399 & 11307 & 15706 & 53252 \\
\hline 18 & 0 & 32266 & 3600 & 1680 & 37546 & 4399 & 11307 & 15706 & 53252 \\
\hline 19 & 0 & 32266 & 3600 & 1680 & 37546 & 4399 & 11307 & 15706 & 53252 \\
\hline 20 & 0 & 32266 & 3600 & 1680 & 37546 & 4399 & 11307 & 15706 & 53252 \\
\hline 21 & 0 & 32266 & 3600 & 1680 & 37546 & 4399 & 11307 & 15706 & 53252 \\
\hline 22 & 0 & 32266 & 3600 & 1680 & 37546 & 4399 & 11307 & 15706 & 53252 \\
\hline 23 & 0 & 32266 & 3600 & 1680 & 37546 & 4399 & 11307 & 15706 & 53252 \\
\hline 24 & 0 & 32266 & 3600 & 1680 & 37546 & 4399 & 11307 & 15706 & 53252 \\
\hline 25 & 0 & 32266 & 3600 & 1680 & 37546 & 4399 & 11307 & 15706 & 53252 \\
\hline 26 & 0 & 32266 & 3600 & 1680 & 37546 & 4399 & 11307 & 15706 & 53252 \\
\hline 27 & 0 & 32266 & 3600 & 1680 & 37546 & 4399 & 11307 & 15706 & 53252 \\
\hline 28 & 0 & 32266 & 3600 & 1680 & 37546 & 4399 & 11307 & 15706 & 53252 \\
\hline
\end{tabular}

Alexander KUNTSMAN and Igor Anatolevich ARENKOV (2019), IBIMA Business Review, DOI: $10.5171 / 2019.334457$ 


\begin{tabular}{|c|c|c|c|c|c|c|c|c|c|}
\hline 29 & 0 & 32266 & 3600 & 1680 & 37546 & 4399 & 11307 & 15706 & 53252 \\
\hline 30 & 0 & 32266 & 3600 & 1680 & 37546 & 4399 & 11307 & 15706 & 53252 \\
\hline 31 & 0 & 32266 & 3600 & 1680 & 37546 & 4399 & 11307 & 15706 & 53252 \\
\hline 32 & 0 & 32266 & 3600 & 1680 & 37546 & 4399 & 11307 & 15706 & 53252 \\
\hline 33 & 0 & 32266 & 3600 & 1680 & 37546 & 4399 & 11307 & 15706 & 53252 \\
\hline 34 & 0 & 32266 & 3600 & 1680 & 37546 & 4399 & 11307 & 15706 & 53252 \\
\hline 35 & 0 & 32266 & 3600 & 1680 & 37546 & 4399 & 11307 & 15706 & 53252 \\
\hline 36 & 0 & 32266 & 3600 & 1680 & 37546 & 4399 & 11307 & 15706 & 53252 \\
\hline $\begin{array}{c}\text { TOTA } \\
\text { L }\end{array}$ & 67500 & 1175466 & 138600 & 57640 & 143920 & 145803 & 416319 & 562122 & 200132 \\
\hline $\begin{array}{c}\text { SHAR } \\
\text { E }\end{array}$ & $3,37 \%$ & $58,73 \%$ & $6,93 \%$ & $2,88 \%$ & $71,91 \%$ & $7,29 \%$ & $20,80 \%$ & $\begin{array}{c}28,09 \% \\
8\end{array}$ \\
\hline
\end{tabular}

\section{Appendix 3}

Table: Perspectives and corresponding key performance indicators for "Grafika"

\begin{tabular}{|c|c|}
\hline № & Perspectives and key performance indicators \\
\hline & "FINANCE" PERSPECTIVE \\
\hline 1 & Reducing the cost of communication \\
\hline 2 & Reducing the cost of contractual and claims activities \\
\hline 3 & Reducing the cost of customer service activities \\
\hline 4 & Profit growth due to the provision of additional services \\
\hline \multirow[t]{2}{*}{5} & Profit growth due to increased reliability of customer service \\
\hline & "CUSTOMERS" PERSPECTIVE \\
\hline 6 & Reduce costs by reducing primary service time \\
\hline 7 & Reduce costs by reducing periodic service \\
\hline 8 & Reduce costs by reducing document preparation time \\
\hline 9 & $\begin{array}{l}\text { Profit growth due to the increase in demand for the company's existing services, } \\
\text { attracting new customers }\end{array}$ \\
\hline \multirow[t]{2}{*}{10} & $\begin{array}{l}\text { Profit growth due to increase of customer satisfaction with growth of service } \\
\text { reliability }\end{array}$ \\
\hline & "BUSINESS PROCESSES" PERSPECTIVE \\
\hline 11 & Reduction of internal document flow costs \\
\hline 12 & Reduction of costs for periodic forced improvement of business processes \\
\hline 13 & Reducing the cost of overcoming employee resistance to change \\
\hline 14 & Profit growth by reducing the inertia of business processes \\
\hline \multirow[t]{2}{*}{15} & $\begin{array}{l}\text { Profit growth due to the overall improvement of business processes in the direction of } \\
\text { improving the reliability of service }\end{array}$ \\
\hline & "EMPLOYEES" PERSPECTIVE \\
\hline 16 & Reducing the cost of training employees in the field of digital technology \\
\hline 17 & Reducing the cost of training employees in modern methods of working with clients \\
\hline
\end{tabular}




\begin{tabular}{|l|l|}
\hline 18 & The reduction of the cost of retaining key employees or training their replacements \\
\hline 19 & Profit growth due to improvement of employees ' ability to work with clients \\
\hline 20 & Profit growth due to General increase of social responsibility of employees \\
\hline
\end{tabular}

\section{Appendix 4}

Table: Indicators of the investment project effectiveness

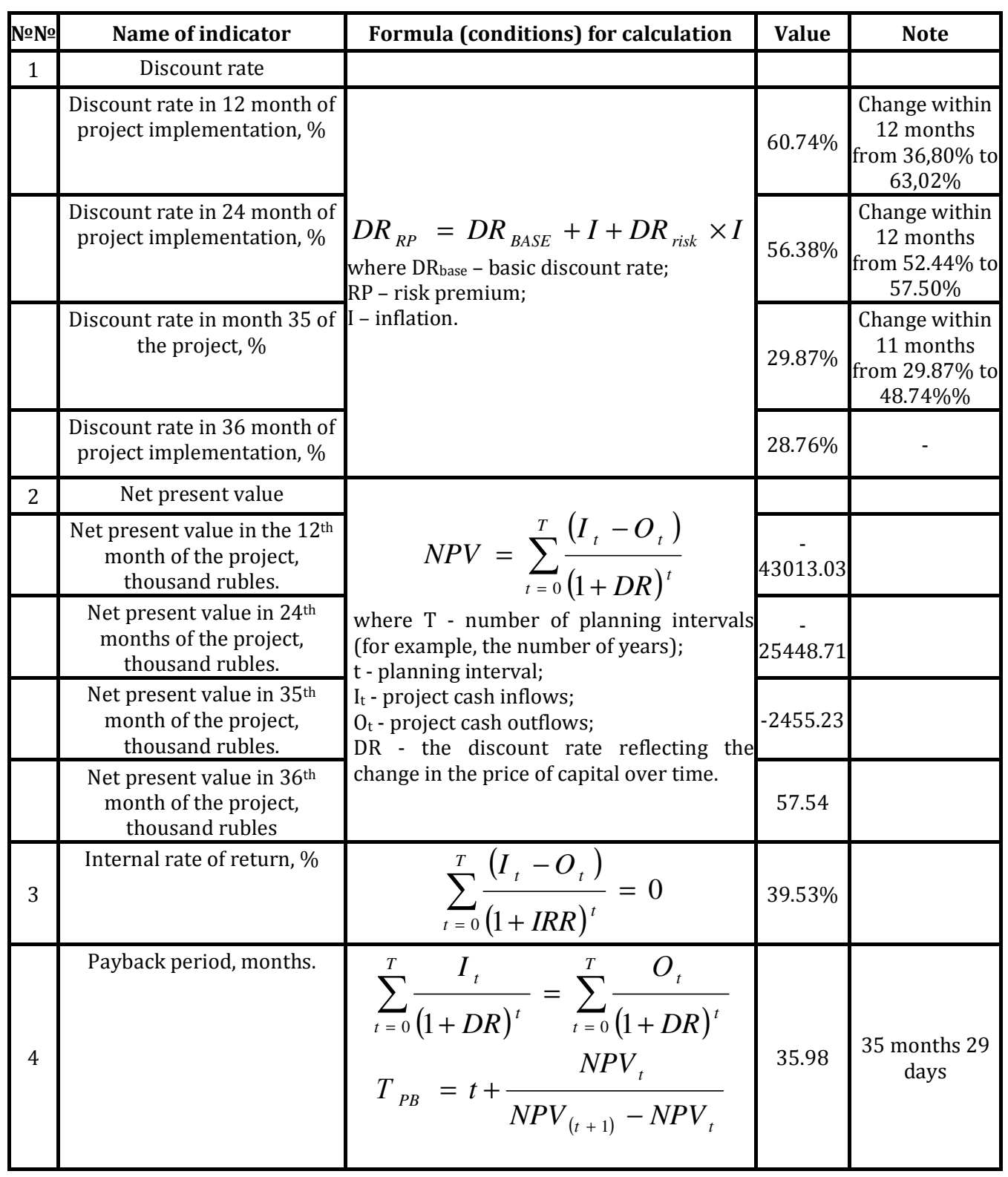




\section{Appendix 5}

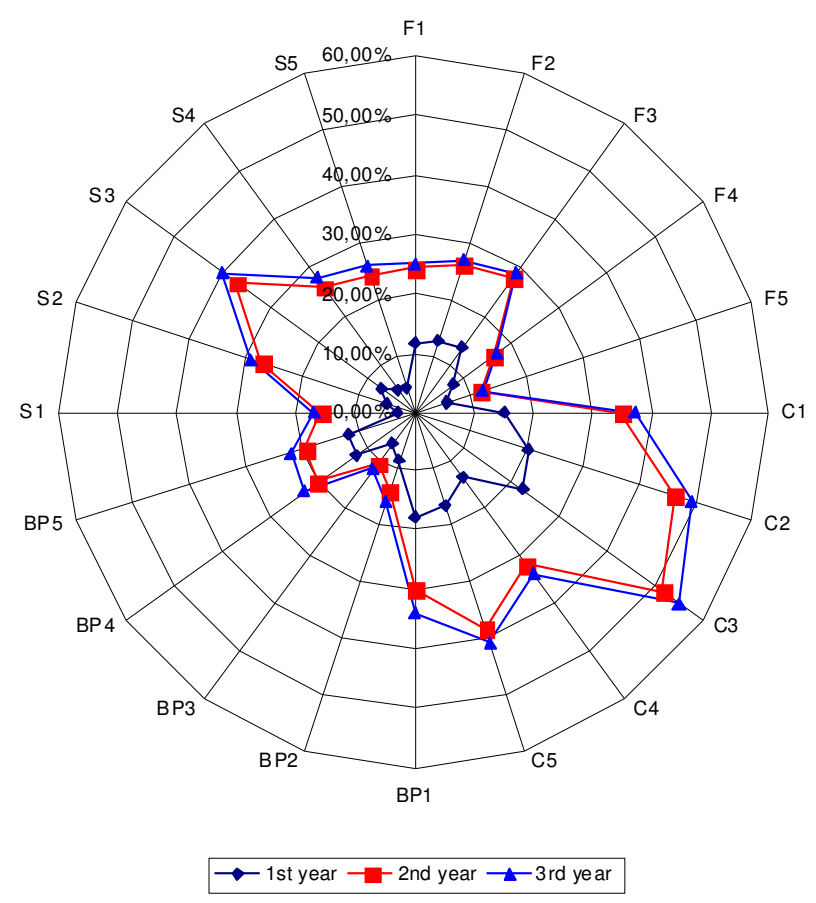

\begin{tabular}{|l|c|}
\hline Key performance indicators (KPIs)) & KPI code \\
\hline Reducing the cost of communication & $\mathrm{F} 1$ \\
\hline Reducing the cost of contractual and claims activities & $\mathrm{F} 2$ \\
\hline Reducing the cost of customer service activities & $\mathrm{F} 3$ \\
\hline Profit growth due to the provision of additional services & $\mathrm{F} 4$ \\
\hline Profit growth due to increased reliability of energy supply to consumers & $\mathrm{F} 5$ \\
\hline Reduce costs by reducing primary service time & $\mathrm{C} 1$ \\
\hline Reduce costs by reducing periodic service & $\mathrm{C} 2$ \\
\hline Reduce costs by reducing document preparation time & $\mathrm{C} 3$ \\
\hline Profit growth due to the increase in demand for the company's existing services, attracting new customers & $\mathrm{C} 4$ \\
\hline Profit growth due to increased customer satisfaction with increased reliability of services & $\mathrm{C} 5$ \\
\hline Reduction of internal document flow costs & $\mathrm{BP} 1$ \\
\hline Reduction of costs for periodic forced improvement of business processes & $\mathrm{BP} 2$ \\
\hline Reducing the cost of overcoming employee resistance to change & $\mathrm{BP} 3$ \\
\hline Profit growth by reducing the inertia of business processes & $\mathrm{BP} 4$ \\
\hline $\begin{array}{l}\text { Profit growth due to the overall improve ment of business processes in the direction of improving the reliability of } \\
\text { services }\end{array}$ & $\mathrm{BP} 5$ \\
\hline Reducing the cost of staff training in the it sector & $\mathrm{S} 1$ \\
\hline Reducing the cost of training employees in modern methods of working with clients & $\mathrm{S} 2$ \\
\hline The reduction of the cost of retaining key employees or training their replacements & $\mathrm{S} 3$ \\
\hline Profit growth due to improvement of employees 'ability to work with clients & $\mathrm{S} 4$ \\
\hline Profit growth due to General increase of social responsibility of employees & S5 \\
\hline
\end{tabular}

Fig. Changes in key performance indicators 